\title{
HISTORY OF THE LIVERPOOL TEACHING HOSPITALS UNTIL 1907
}

by

\author{
JOHN A. ROSS
}

KING John gave us a charter but little good came of it because Liverpool remained a small fishing village for a long time owing to the difficulty of access, not only to the town but to the port. In the seventeenth century ships became more efficient and trade had now expanded outside the confines of the Irish sea. Daniel Defoe in his book, A Tour through the Whole Island of Great Britain points out that in 1709 the citizens 'made a large basin or wet dock . . . where, at immense charge . . . they brought the tide from the Mersee ... and the ships lye as in a millpond ... the like is not to be seen in any place in England'. Defoe writes of 'the fineness of the streets ... the beauty of the buildings ... . many of the houses all of free stone . . . as handsomely built as London itself'. High praise indeed. He must have seen it in fine weather because others later wrote of narrow streets, by no means clean, and badly drained. Indeed towards the end of the century William Moss, a Liverpool surgeon, wrote a guide to Liverpool with the object of ventilating matters 'needing attention' and mentions that the poorest people live overcrowded in cellars, intemperate in habits and neglectful of their children. The expectation of life in Liverpool in the early nineteenth century was less than in most other places.

New factors were making an impact, notably the Assiento Pact of 1713, which allowed Britain to regulate the slave traffic, which was mainly conducted from London and Bristol with Liverpool entering as a competitor. Slaves were not sold in these ports but the trade was a shipowner's dream because he was never compelled to sail an empty ship. He took merchandise to Africa, loaded in exchange a cargo of slaves which he sold in the West Indies or America, then loaded with sugar in the West Indies for delivery to England. It was a fully-laden triangular trip. From America, indigo and rice were shipped, but later cotton became the most important crop. It was because of sugar imports that Liverpool became and still remains the main centre of sugar refinery. Liverpool became wealthy and fortunes were made, amongst others, by the Gladstone family, while in 1798 Pitt stated that of the overseas trade revenues no less than four-fifths came from the West Indies.

Liverpool had surpassed Bristol because the latter was not favourably placed; in the hinterland of Liverpool, Lancashire factories had grown apace during the industrial revolution and they required an outlet for their goods. Lancashire was building its 'dark, satanic mills'; Liverpool was building its dark, satanic warehouses. Canal transport, booming in 1760, had made conveyance of goods easier. In Britain, the earlier agricultural revolution had improved food supplies and increased the population. All seemed set fair.

The increasing population necessitated a proper provision for the sick so that the 
Infirmary was opened by the 11 th Earl of Derby in 1749 . Over the gate the following lines were inscribed:

Think while your hand th' entreated alms extend

That what to US ye give- to God you lend.

The citizens obtained good value reminding me of the old Victorian hymn which runs: 'Whatever Lord we lend to thee Repaid a thousand fold will be'.

The Infirmary paid dividends even though it only contained fifty-four beds. It represented a splendid act of charity on behalf of the citizens, but it was also a necessity because shipowners and others supported it to serve the needs of their servants, sailors and dependants. In addition there was a Seaman's Hospital, or rather hospice, under separate management, to care for sailors and their families. The old Infirmary was replaced in 1824 by a new one in Brownlow Hill designed by John Foster 'If not his most inspired offering, its portico, six fluted columns in dry, classical style pinioned by plastered antae, had a certain monumental dignity'. This in turn gave way in 1887 to the present Gothic building designed by Alfred Waterhouse.

The original building did not please everyone including John Aitken, one of its surgeons, who considered that the wards were dangerous owing to overcrowding, but the trustees had reason to be thankful because all debts had been paid off by 1752 and for the time being Liverpool's problems were solved. In Liverpool at the end of the century, as in Edinburgh, the Athens of the North, Birmingham with its Lunar Society and in other places, there was an unusual flowering of intellect dominated by Roscoe and Currie. In medicine the names of Currie, Park, Alanson and Matthew Dobson spring to mind, men who recorded their observations with scientific care. Dobson's description of the diabetic youth is a model record of exact observation.

After the Napoleonic wars Liverpool was visited by Baron Larrey who crossed the Mersey by what he called 'the ancient Birkenhead route'. He said that 'they esteemed the crossing rather perilous'. Larrey stayed at the Hotel de Paris and was entertained by Dr. Joseph Brandreth and by another physician even on Sundayhe said, 'a rare event in England since this day is set aside for prayer and repose'. He saw the sights including the Royal Institution with its museum which he duly admired. The docks entranced him but 'amongst these splendid ships was a steamer, blackened with smoke and dark paint, bringing to Liverpool Irish immigrant families, clad in rags and seeking to escape from that ungrateful country with its horrors and misery, to find a livelihood in this hospitable town'. Larrey was taken to the Infirmary and he was not happy about the surgical treatment particularly of fractures and he says 'the surgeons were grateful for some suggestions' and he gave a demonstration of his own methods. He ends by writing - 'we have nothing but praise for the kindness and attention of these doctors and surgeons of this town'.

By a curious chance it was the slave trade that initiated medical education in Liverpool and this was done by men known as 'the African Surgeons'. In the eighteenth century medical qualifications were variable, so that it was necessary for candidates for surgical appointments in the Navy to submit to the examining board of the Company of Surgeons in London, vividly described in Roderick Random by Tobias 


\section{History of the Liverpool Teaching Hospitals until 1907}

Smollett, himself a victim and whose own qualifications were decidedly slender. Conditions in the slave traders were so bad that an Act of Parliament was passed in 1789 compelling owners to carry a surgeon in each ship. To select suitable men a licensing board was set up in Liverpool and it examined 634 surgeons between the years 1789 and 1807 rejecting no less than 151 . The examinations were held at the Infirmary monthly as required, successful candidates paying a fee of 3 guineas with 5s. $0 d$. for the secretary. Unsuccessful candidates paid $5 s$. $0 d$. only to the secretary. Additional fees were levied if special examinations had to be arranged. The following members of the Infirmary staff served on the board-Joseph Brandreth, James Currie, James Gerard, Henry Park, John Lyon and Edward Alanson.

The Infirmary was taking pupils by permission of the Trustees although the first recorded payment was in 1802 . An improved education was becoming necessary so that, as in London and other towns, anatomy schools were founded to enable pupils of local doctors and the Infirmary pupils to obtain a better preliminary training. Gill's and Formby's Schools are mentioned in the Report from the Select Committee in Anatomy (1828). There were about forty students, including sculptors, painters and others besides medical students, studying at two schools, one in charge of Richard Formby and the other founded by William Gill, later surgeon to the Northern Hospital. According to Dyce Duckworth, Formby never had a large practice nor was he a favourite with his brethren but was of independent means and mainly interested in teaching. He had been a pupil at the Infirmary before going up to Cambridge in 1808.

Prior to the Anatomy Act there were scandals due to the activity of the resurrectionists as in other towns. At one time bodies destined for Edinburgh, were shipped to Liverpool from Dublin. William Gill was implicated in resurrectionist activity; the body of a young woman buried in Walton was found in the cellar of a house which he owned in Seel Street. Gill was very fortunate to be discharged by the magistrates. The schools required 24-28 bodies annually, costing 3-7 guineas each. Bodies were more easily procured from Dublin and they cost from 3-5 guineas each, but they were liable to seizure by customs officials.

From as early as 1811 , lectures were given at the Liverpool Dispensary, which had been built in Church Street in 1778. Sir Zachary Cope has pointed out that the Free Dispensaries played a considerable part in medical education in Britain. Later the lectures were given in the Royal Institution in Colquitt Street.

In 1833, the physicians and surgeons of the Dispensary required beds so that there was an agitation to found a new hospital, made necessary because the Infirmary could no longer cope with the vastly increasing population, particularly at the north end of the town. The result was the founding of the Northern Hospital notably supported by the reformed Council and men like Dr. James Carson, described as 'an old practitioner of the town'; William Brown, later Sir William, and a distinguished Chairman of the Northern, was also present. Pupils were taken as early as 1835 when an unnamed 'Sir George Drinkwater's nephew' became pupil to Dr. Squires, and later both out-door and in-door pupils were taken. In 1838 the Court of the Royal College of Surgeons recognized the hospital as a teaching hospital and this resulted in a move to a new building designed by Welch who was the architect 
of Birmingham Town Hall. Recognition was also granted by the Society of Apothecaries.

In 1847 one of the hospital rules read: 'Such apprentices and pupils as are necessary for the Hospital shall be admitted by the General Committee, whom they shall have also power to discharge'. This might have been worded more accurately! Out-pupils paid 12 guineas per annum while Resident pupils paid 60 guineas. By this date the north end of the town had become overcrowded mainly by a vast influx of Irish people, who, fleeing from poverty in Ireland, found it, once again, in the slums of Liverpool. They came either to find a ship in which to emigrate to America or to find work at the docks. Naturally the shipowners welcomed them as cheap labour but they created a problem of their own. The numbers were yet again increased when the potato famine aggravated Irish problems in 1845.

Incidentally, at a much later date, the Northern became the first hospital in Europe to have its own ambulance, originated by Reginald Harrison, one of Britain's first urological surgeons, who wrote many pamphlets in its support. It cost $£ 227$ a year to run and it cost the hospital more to hire the horse than to pay its driver. 'The average time of each journey from call to return was 18 minutes 30 seconds' according to Harrison. A houseman or a student had the duty of accompanying the driver and the ambulance was equipped with drugs, splints, instruments (including a tracheotomy tube) and dressings, so that the patient had intensive care from door to door. Of course, prior to this patients were transported in a litter; but it should be said that if you lived in Glasgow you could be taken to hospital in a sedan chair, provided by the Royal Infirmary in 1794 .

In 1842 it was necessary to build yet another hospital which became the Royal Southern Hospital caring for the needs of the South end of the town. It moved to a new building in 1872 and was recognized as a teaching hospital by the Royal College of Surgeons in 1857 and by the Society of Apothecaries in 1870, because it then had two physicians, which were required by rule. In 1867 the city had again extended north into Kirkdale leading to the establishment of the Stanley hospital.

Lectures were given at the Royal Institution at an early date. In 1816 John Bostock was lecturing in physiology. Bostock's mother was doubtful of her son's powers of delivery. After the grant of the Charter to the Royal Institution, from 1819 Dr. T. S. Traill lectured, as professor of chemistry, twice weekly for three months and included other subjects-meteorology and hydrology. Sir James Smith was professor of botany, Dr. Richard Formby of anatomy while John Bostock, a Fellow of the Royal Society, professed physiology. Traill was appointed professor of forensic medicine in Edinburgh and was therefore succeeded by Dr. Reynolds of the Northern Hospital. Bostock moved to London but continued to hold the title of professor until his resignation in 1831.* However, physiology lectures were given by Dr. Formby in 1830 and 1832 and by Dr. Peter Roget in 1829. Roget became secretary of the Royal Society, a sort of éminence grise of Science, although better known as the author of the Thesaurus.

In 1834 the Royal Institution founded a School of Medicine and Surgery which functioned for ten years. The pupils were taken over by the Royal Infirmary School

* Bostock was the author of a work on physiology and a distinguished member of many scientific societies. He has a claim to fame for the original description of hay fever. 


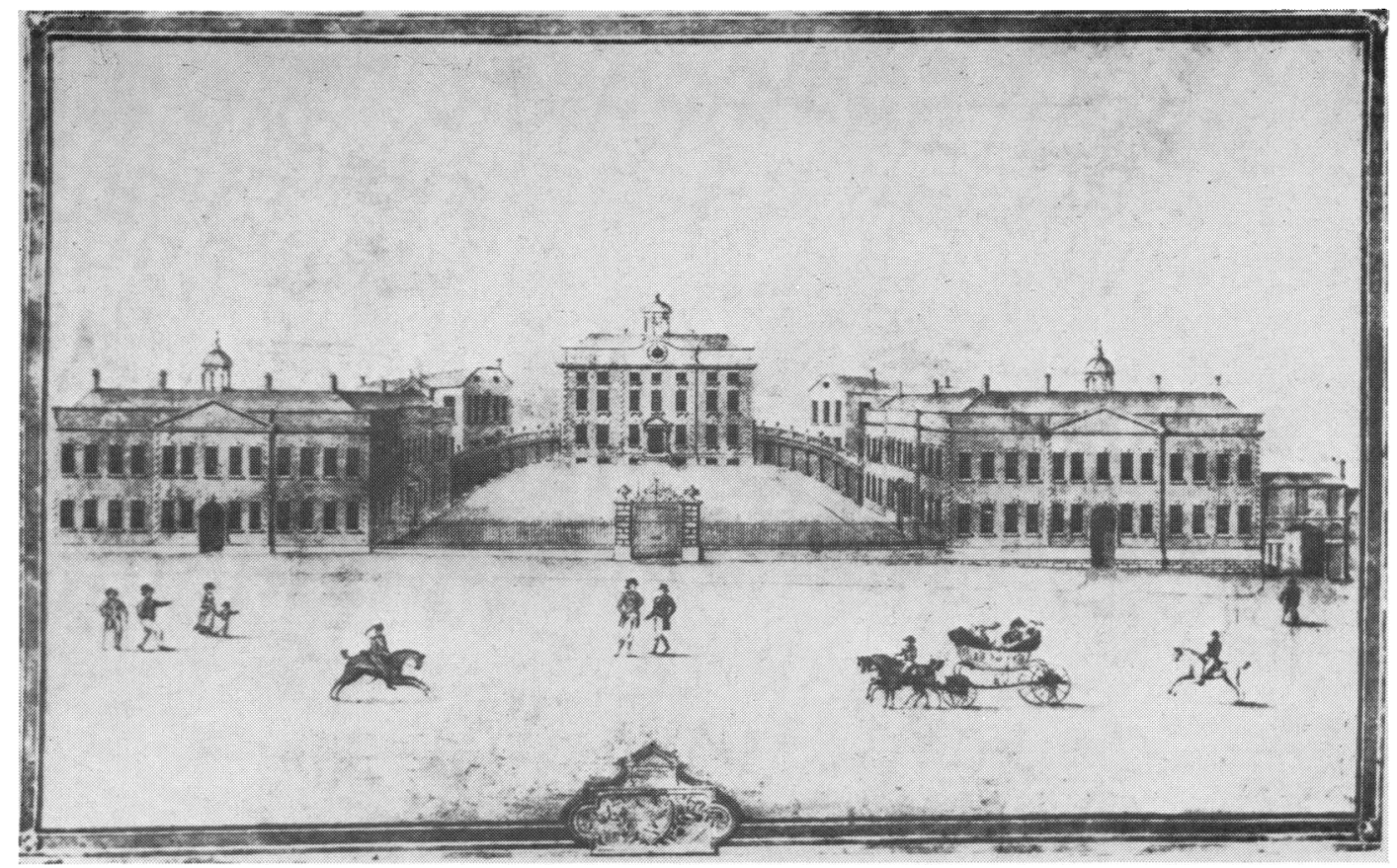

Figure 1

The Infirmary and Seamen's Hospital with the Medical Library on the extreme right, c. 1813.

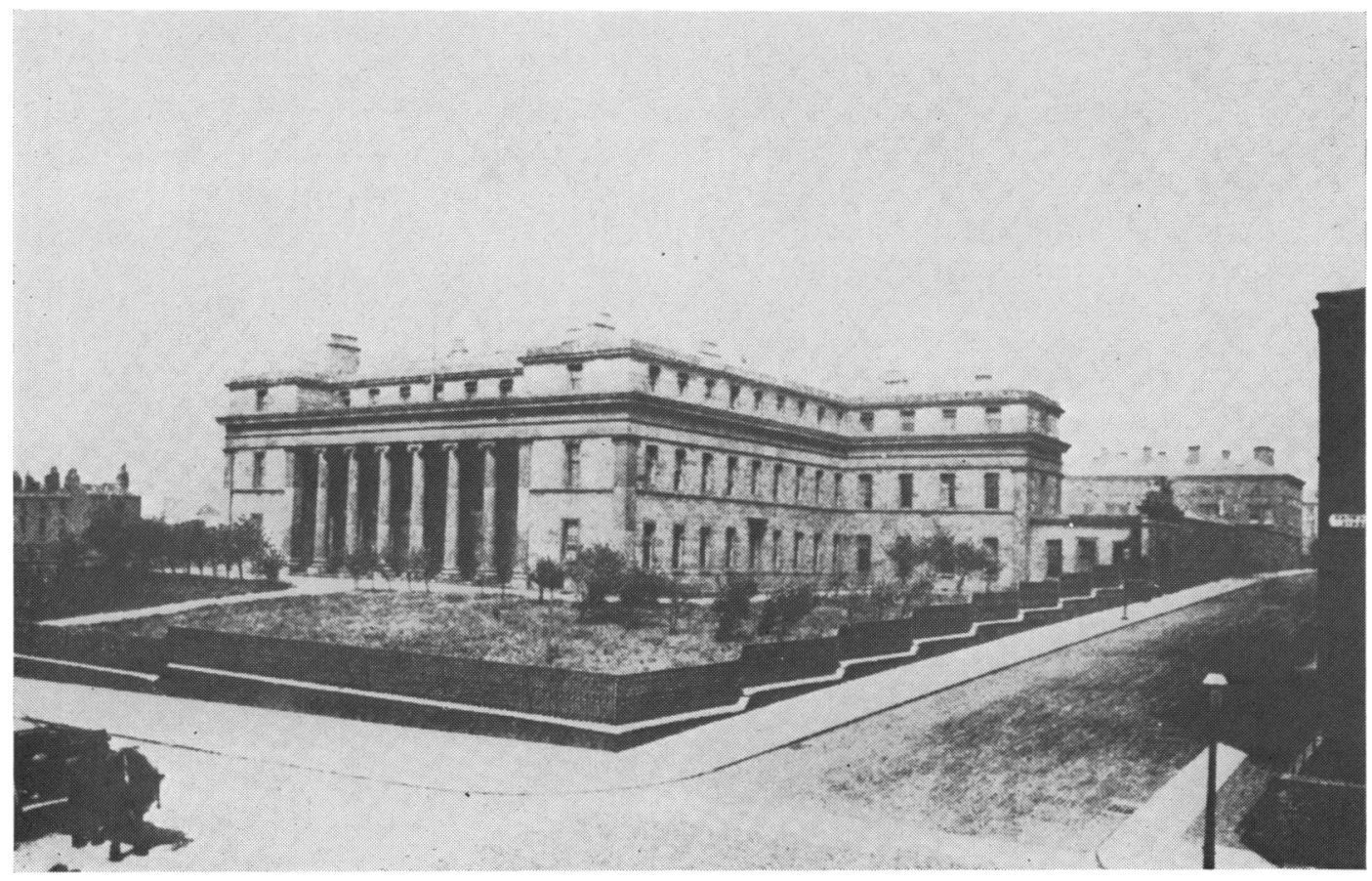

Figure 2

The second Infirmary, Brownlow Street, 1824-1890. 


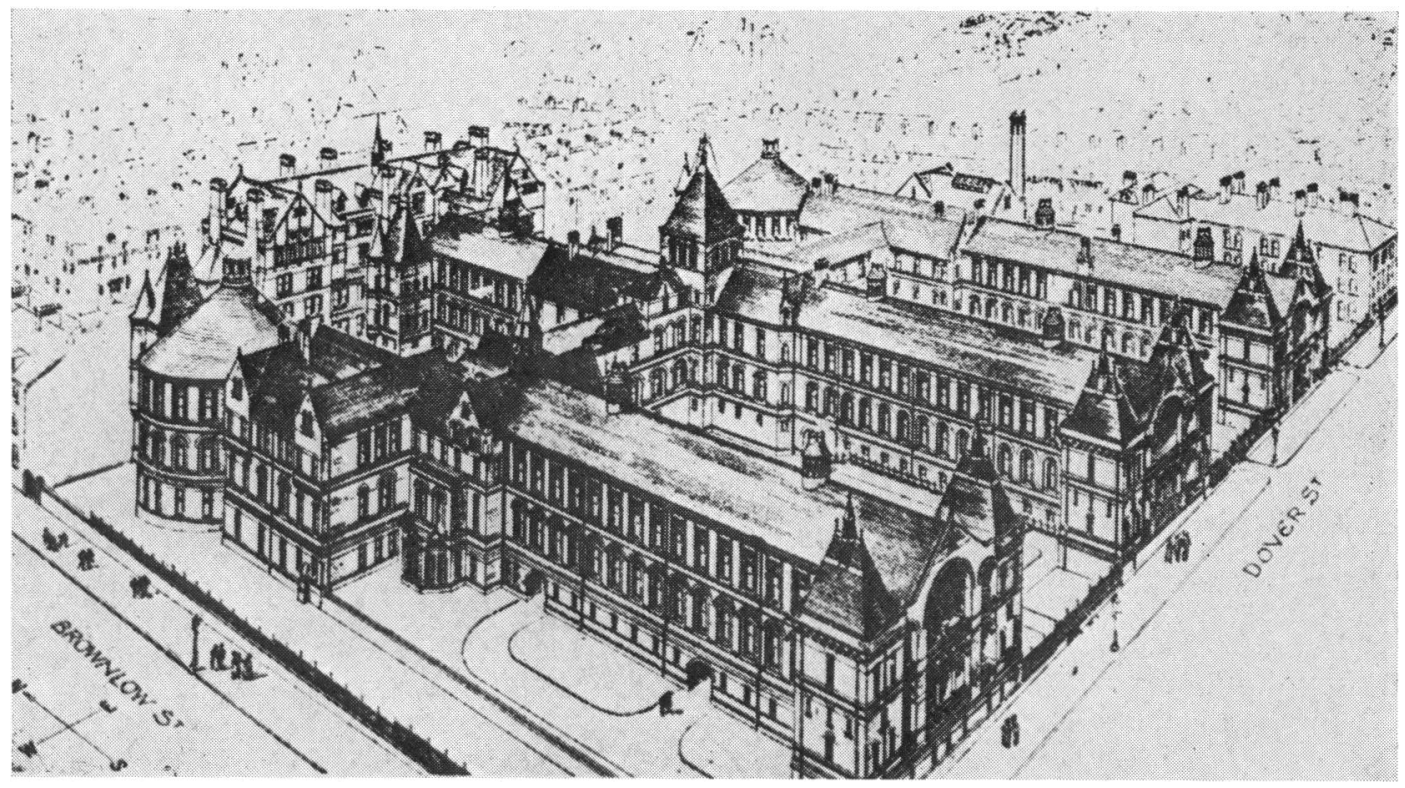

Figure 3

The Royal Infirmary, 1890.

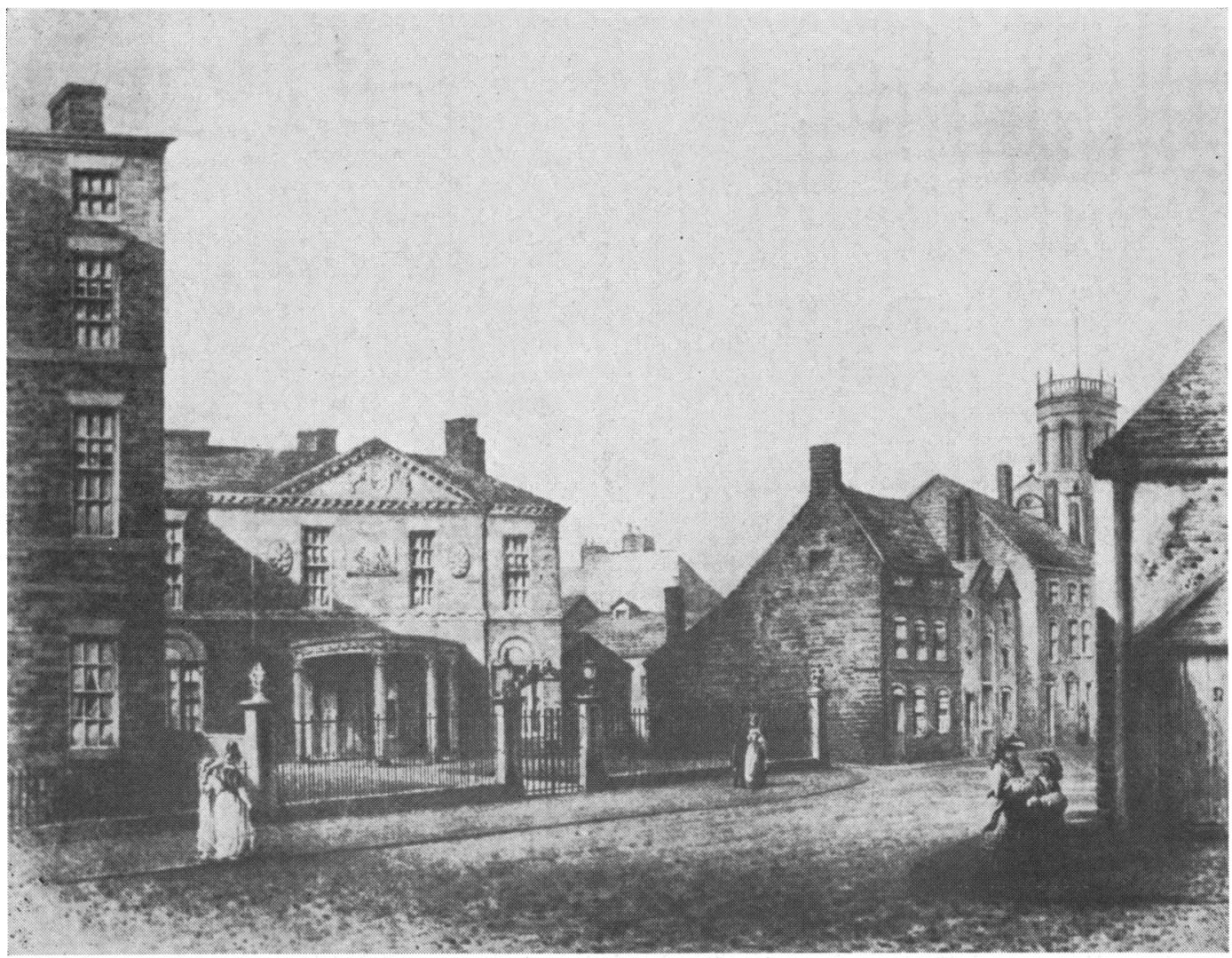

Figure 4

Church Street in 1798, showing the Dispensary from 1782 to 1829. 


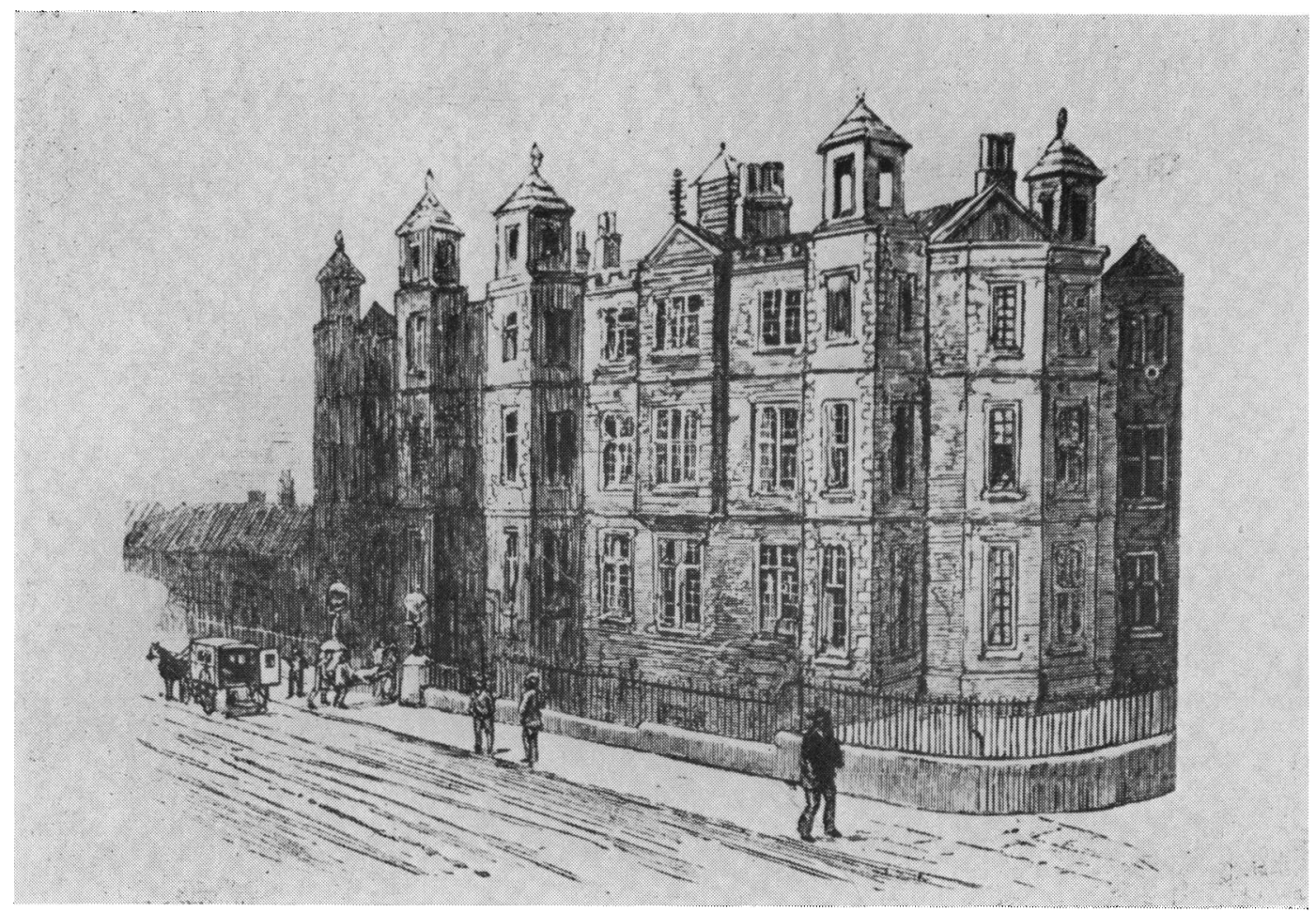

Figure 5

The Northern Hospital, Great Howard Street, 1845-1900.

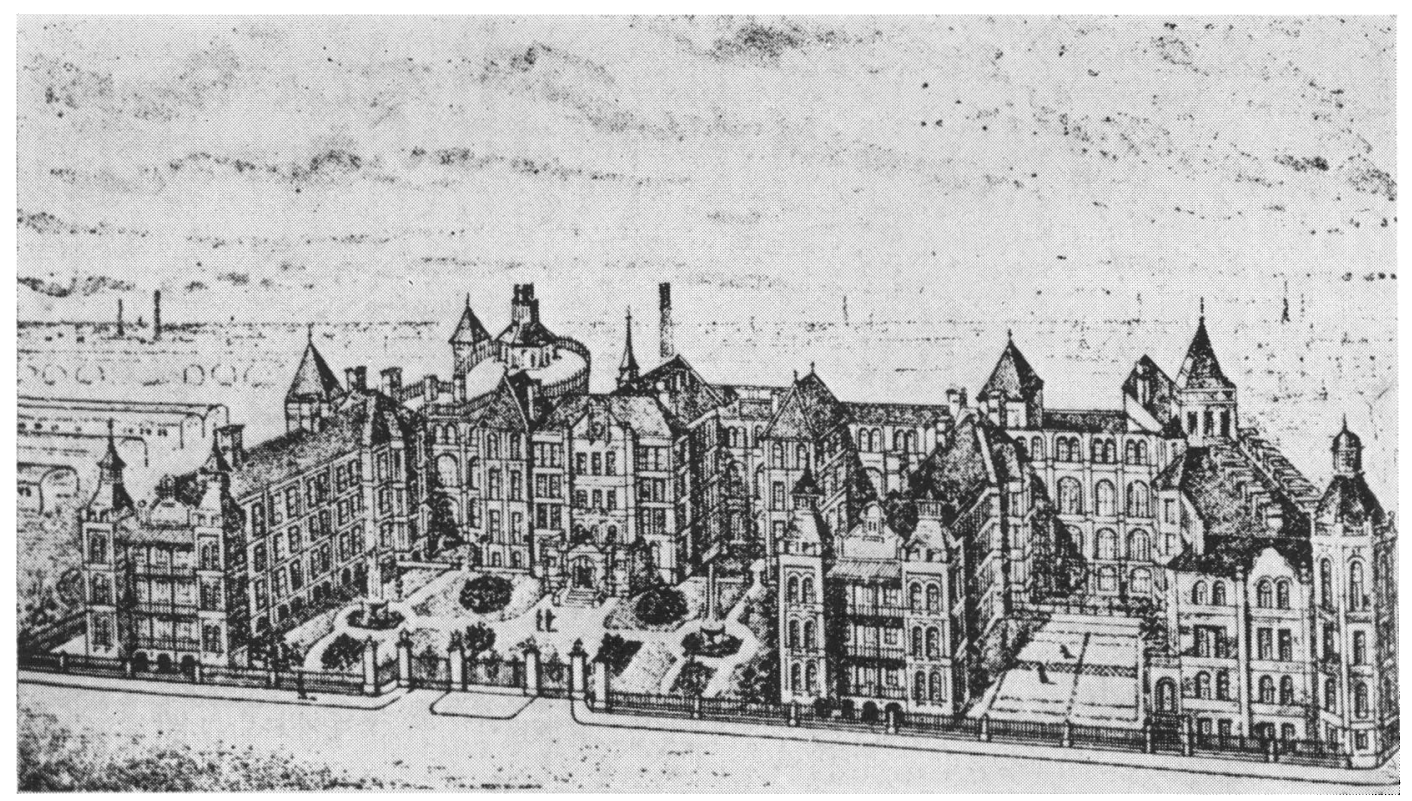

Figure 6

The David Lewis-Northern Hospital, Great Howard Street, 1900. 


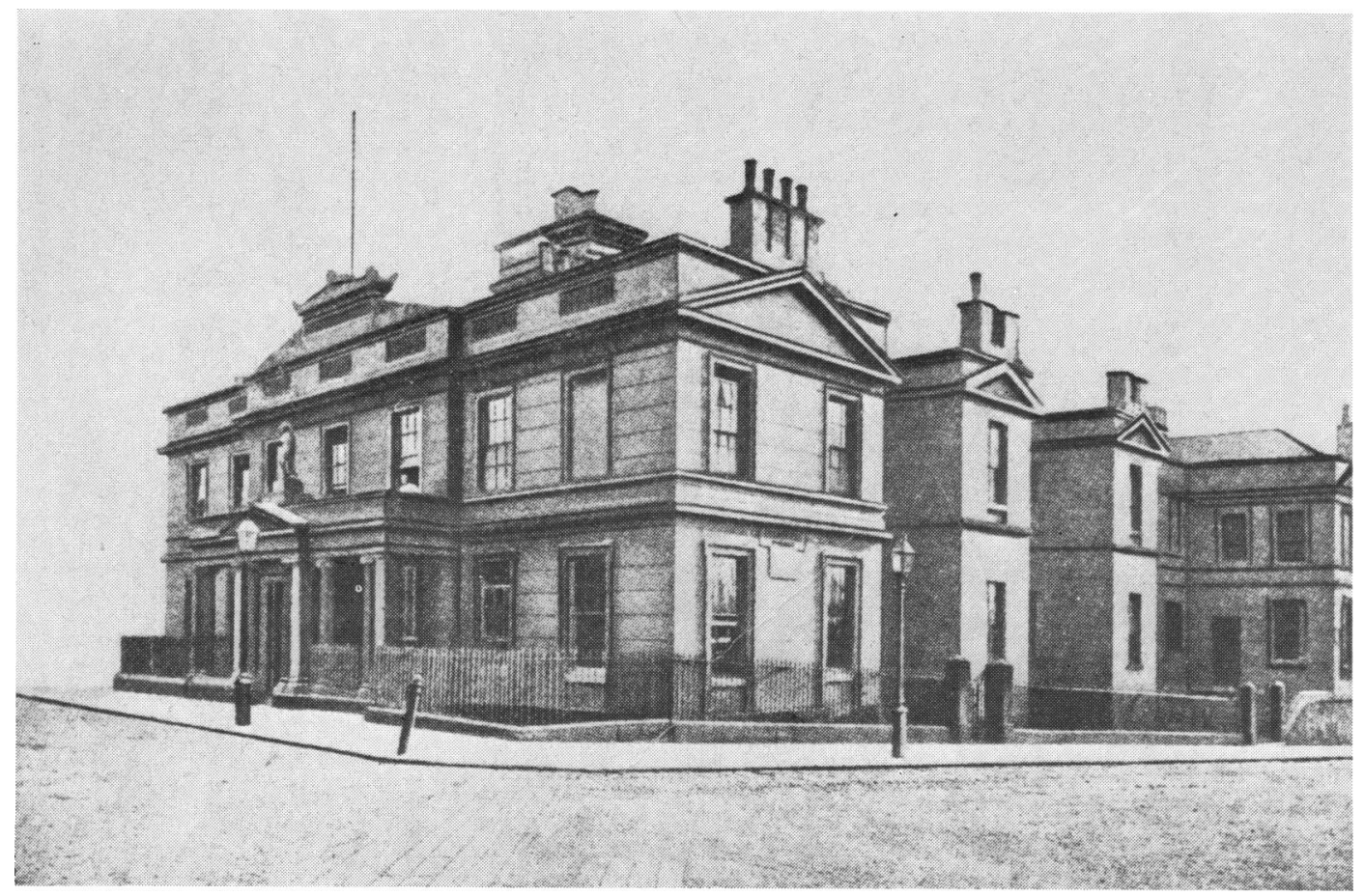

Figure 7

The Southern and Toxteth Hospital, Greenland Street, 1842-1872.

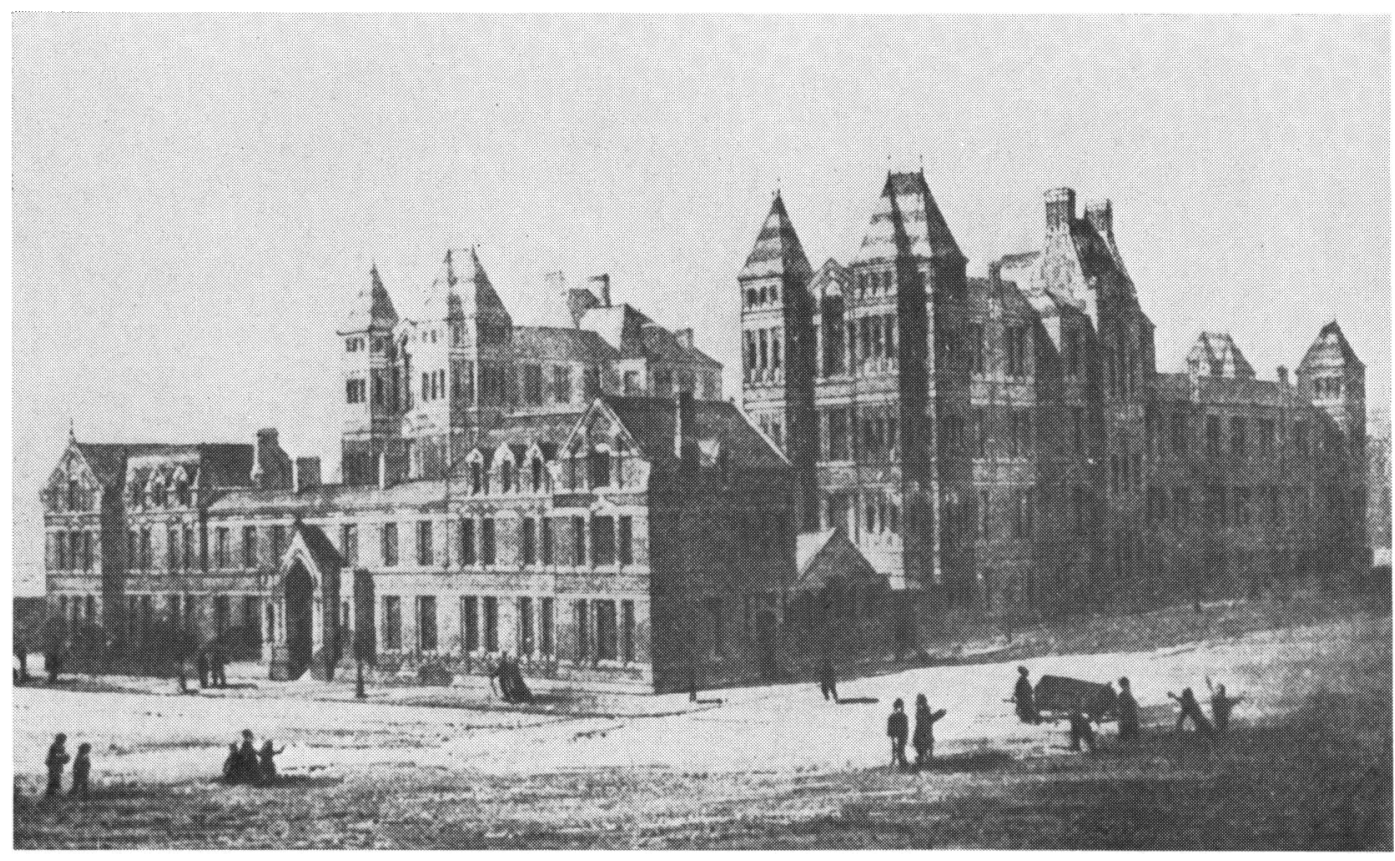

Figure 8

The Royal Southern Hospital, Caryl Street, 1872. 


\section{History of the Liverpool Teaching Hospitals until 1907}

of Medicine which opened in new premises in Dover Street in 1846, catering for indentured pupils of the district (the so-called 'out-pupils'). This followed the London pattern where the school was closely linked with the hospital. The Infirmary itself had six students (clerks and dressers), one for each consultant. The advantage to students was that they could study without having to spend too much time in London and 'without', as the Trustees suggested, 'being exposed to the danger from a too early freedom from restraint amongst the temptations of the Metropolis'. The teaching was carried out by Infirmary staff assisted by those from the other hospitals. The school prospered well and gave instruction in all subjects required by the Society of Apothecaries-anatomy (140 lectures), chemistry (40 lectures), medicine, surgery, materia medica, botany and medical jurisprudence. Lectures on midwifery were given by Mr. E. Batty of the Ladies' Charity. In 1865 there were twenty-eight students at the school. Gemmell quotes some observations made by Professor T. R. Glynn. Incidentally, Professor Glynn when appointed a house surgeon was an M.B. of London, and also M.R.C.S. and L.R.C.P. The appointment was cancelled because he was not an L.S.A.; it was a rule that a junior must hold this qualification. He said that after 'a period of stagnation' further impetus was given by new men-Reginald Harrison, the surgeon, who acted as Registrar (or Dean) and lectured in anatomy and later clinical surgery; Frederick Roberts, a keen, gifted teacher and author of a well-known textbook; W. H. Duncan also lectured in medical jurisprudence. Students increased from 15 in 1864 to 103 in 1874, necessitating an extension of the buildings in 1867. In 1871, the Committee of Management consisted of Nevins, Harrison, Cameron, Bickersteth, Caton, Mitchell Banks, with A. T. H. Waters as Treasurer. The school ceased to be run by the Infirmary Medical Board and was run by a Council drawn from the three major hospitals. At this date, the curriculum had been increased and lectures were also given in surgical anatomy, physiology, pathology and comparative anatomy with zoology.

Specialist training could be carried out at an early date by attendance on the staff of the Ladies' Charity, which was the origin of the Maternity Hospital. A Lunatic Asylum had been established near the original Infirmary and although it was staffed by talented men, they did not show particular interest in mental disorders so that we were no more enlightened in Liverpool than elsewhere. An Ophthalmic Infirmary was established in 1820 and later an Institution for the Treatment of Ear Diseases, both combining in 1841 to form the Eye and Ear Infirmary, which became part of the teaching hospital, another branch of which, the Royal Liverpool Children's Hospital, was founded in 1851. Other specialized institutions were founded, such as the Dental Hospital in 1860.

The mid-Victorians were men of great ability, a small but talented élite. The Bickersteth family, dividing their loyalties between medicine and the Church, dominated medicine and surgery until the turn of the century, perhaps overshadowing other equally distinguished men, such as Hakes, said to be 'one of the best surgeons in the Country', Alfred Higginson and Hugh Owen Thomas. Later Mitchell Banks and Rushton Parker were the most noted surgeons, while the young Richard Caton made a niche for himself in medical history as the unrecognized discoverer of electrical impulses from the cerebrum. 
It is not by coincidence that the university backs on to Dover Street, because it started simply as an extension of the Medical School and was built on the site of the Lunatic Asylum which had followed the Infirmary up the hill in 1830. The beginnings of the university can be traced back to 1876 when the Medical School, owing to changes in the regulations of London University, required a lecturer in physics, so they appealed to the public for funds to start endowments, a reasonable request considering the great public service which it was rendering. It is interesting to note that Dr. James Carson as early as 1836 urged the town council to found a university. A joint committee with prominent local people decided to discuss with the Corporation the formation of a university college. A chair of physics was endowed in 1880 and the college received its charter in the following year. Combining with the Leeds and Manchester colleges to form the Victoria University, it was possible to grant degrees. The University of Liverpool was granted its own charter in 1903. During all these years new departments were built and new chairs endowed in medical and pre-medical subjects. It is significant that the Statutes of the University make research obligatory.

Towards the turn of the century new minds, cultivated by the considerable advances of mid-Victorian days, brought new ideas and a modern outlook for the millennium. Liverpool could boast that Sherrington and Augustus Waller were teaching physiology Oliver Lodge physics, Robert Jones orthopaedics, Ronald Ross and Rubert Boyce tropical medicine. It was Lodge who introduced Jones to 'the new kind of ray' in 1896 and from this Thurston Holland set off on his distinguished career in Radiology. All these men were pioneers.

Although the School was in being the hospitals were entirely unco-ordinated. The Northern, Southern, Eye and Ear Infirmary and the Women's Hospital were all recognized by the university and the conjoint boards in London and Scotland. K. W. Monsarrat, a distinguished surgeon and teacher, persuaded these hospitals to combine to form a Clinical School, which later in 1907 combined with the University Clinical School, thereby considerably widening the basis of clinical teaching and providing new scope.

\section{REFERENCES}

Bickerton, T. H., A Medical History of Liverpool, London, 1936.

COPE, Z., 'The influence of the free dispensary in medical education in Britain', Med. Hist., $1969,13,29-36$

Defor, D., A Tour through the whole Island of Great Britain 1724/26.

DiBLE, J. H., Napoleon's Surgeon, London, 1970.

Gemmel, A. A., Liverpool Medical School, Liverpool University Press, 1934.

Harrison, R., The Ambulance in Civil Life, London, 1902.

Harrison, R., The Use of the Ambulance in Civil Practice, Liverpool, 1881.

HARrison, R., Retrospects and Prospects relating to University Life, London, 1905.

Hughes, Q., Architecture and Landscape of Liverpool, London, 1964.

KINGsford, P. W., 'A London merchant', Hist. Today, May 1971.

KuTz, H., 'Europe in the Caribbean', Hist. Today, May 1971.

MACAlister, C. J., A Short History of the Royal Southern Hospital, Liverpool, 1923.

Moss, W., A Medical Survey of Liverpool, Liverpool, 1784.

Northern Hospital, Minute Books. 
Ormerod, H. A., Liverpool Royal Institution, Liverpool University Press, 1953.

ORMEROD, H. A., Early History of the Liverpool Medical School from 1834-1877, Liverpool, [n.d.].

Picton, J. A., Architectural History of Liverpool, Liverpool, 1858.

Picton, J. A., Memorials of Liverpool, 2 vols., London, 1873.

Report of The Select Committee on Anatomy, 1828.

Simpson, G., 'Liverpool of our founders', Lpool med.-chir. J., 1937, 45.

\section{HISTORY OF ANAESTHESIA IN LIVERPOOL}

\section{by}

\section{T. CECIL GRAY}

BEFORE telling the story of anaesthesia in Liverpool, it is interesting to take note of our 'near misses' in subjects which have, in later years, become of importance in anaesthetic practice.

James Currie, a physician of this city who died in 1805 , was a pioneer in the study of hypothermia. His was the earliest record of the therapeutic use of cooling to reduce pyrexia. He made observations on this condition which remain valid today, including the drop of temperature which occurs when the individual is removed from the cold environment-the so-called 'after drop'. This is of importance in the technique when using the surface cooling method. His observations were made on individuals who had fallen into the Mersey and had remained in the water for some time (Currie, 1798).

Perhaps the most interesting 'near miss' lies in the interest that Alfred Higginson took in respirology. Higginson was a surgeon to the Royal Southern Hospital, one of the founder members of the Liverpool Medical Institution and the immortal inventor of the syringe which probably in its day relieved more pain and discomfort than most drugs, other than anaesthetics, by affording relief to so many over-burdened colons. He attended the first demonstration of ether anaesthesia in the city and was at once intensely interested and saw the importance of the discovery. He quickly constructed an ether inhaler from an ear trumpet and bladder. He had an inventive brain and designed, among a great variety of 'gadgets', various astronomical instruments, but it was in the field of respirology that he showed himself far ahead of his time. He designed a 'spirometer' with which the vital capacity, a parameter which had just been described by Hutchinson, could be rapidly measured. In years before the introduction of ether there occurs in the Minutes of the Institution the following record: 'Mr. Higginson exhibited and explained a newly invented apparatus for producing artificial respiration, called "the pneumatic chest"; this, we find, consisted of an airtight box upon which a pair of bellows is placed for the alternate introduction and withdrawal of air. The effect is to force air into the lungs by the elevation of the chest consequent on the abstraction of air from the box'. 